\title{
MEKANISME PEMBUBARAN PARTAI POLITIK DI INDONESIA
}

\author{
Ramot H.P Limbong, I Gusti Bagus Suryawan, I Nyoman Sutama \\ Fakultas Hukum, Universitas Warmadewa, Denpasar - Bali, Indonesia
}

\begin{abstract}
Abstrak
Partai politik dapat dilihat sebagai badan hukum yang dapat dimintai pertanggung jawaban secara pidana karena dilihat dari karakterisik partai politik adalah badan hukum. Pembubaran partai politik menjadi salah satu isu hukum yang diatur dalam peraturan perundang-undangan di Indonesia. Berdasarkan latar belakang ini, penelitian ini dilakukan dengan tujuan menguraikan bagaimana kewenangan Mahkamah Konstitusi dalam pembubaran partai politik di Indonesia dan bagaimana mekanisme pembubaran partai politik. Penelitian ini didesain dengan menggunakan pendekatan penelitian hukum normatif dan pendekatan perundang-undangan. Sumber bahan hukum yang digunakan adalah sumber bahan hukum primer dan sumber bahan hukum sekunder. Teknik pengumpulan bahan hukum yang digunakan yaitu teknik studi pustaka. Bahan hukum yang dikumpulkan diolah dan dianalisis dengan menggunakan argumentasi hukum. Hasil analisis data penelitian ini menunjukkan bahwa pasal 73 ayat (1) UU No. 24 Tahun 2003 tentang Mahkamah Konstitusi menentukan pelaksanaan putusan pembubaran partai politik dilihat didalam pasal71, dilakukan dengan pembatalan pembubaran dalam peme rintah. Selain itu, prosedur perkara pembubaran partai politik di Mahkamah Konstitusiadalah dimulai dari pengajuan permohonan, pendaftaran permohonan dan jadwal sidang, pemeriksaan pendahuluan, pemeriksaan persidangan, rapat permus yawaratan hakim, putusan Mahkamah Konstitusi. Pembubaran partai politik dapat berakibat terhadap hak dan kewajiban eksternal, akibat terhadap jabatan yang terpilih, akibat terhadap status pengurus dan anggota serta akibat terhadap hak dan kewajiban internal.
\end{abstract}

Kata Kunci: Mekanisme, Partai Politik, Pembubaran

\begin{abstract}
Political parties can be seen as legal entities that can be held criminally liable because characteristically political parties are seen as legal entities. The dissolution of political parties is one of the legal iss ues that is regulated in Indonesian laws and regulations. Based on this background, this research was conducted with the aim ofoutlining how the authority of the Constitutional Court in the dissolution of political parties in Indonesia and how the mechanism of dissolution of political parties. This research was designed using a normative legal research approach and a legislative approach. Sources of legal materials used were primary legal sources and secondary legal sources. The legal material collection technique used was literature study technique. Legal materials collected were processed and analyzed using legal arguments. The results of the analysis of this research data indicated that article 73 paragraph (1) of Law no. 24 of 2003 concerning the Consti tutional Court determine the implementation of the decision to dissolve political parties seen in article 71, carried out by canceling the dissolution in the government. In addition, the procedure for the dissolution of political parties in the Constitutional Court is to begin with the submission of applications, registration of requests and trial schedules, preliminary hearings, trial hearings, judges' deliberations, decisions of the Constitutional Court. The dissolution of political parties can have an impact on external rights and obligations, the elected officials, the status of management and members as well as the internal rights and obligations.
\end{abstract}

Keywords: Mechanism, Political Parties, Dissolution

\section{PENDAHULUAN}

Konsep Negara hukum yang demokratis adalah Negara yang memiliki gagasan dan kekuasaan tertinggi yang dalam suatu pemerintahan adanya keadilan dan kedaulatan yang berada di tangan rakyat. Kekuasaan yang tertinggi dalam Negara hukum adalah aturan hukum. Dari sisi konsep Negara hukum, hukum mencerminkan kepentingan dan keadilan rakyat karena hukum itu dibuat melalui demokrasi. 
Semua aturan hukum yang dibuat melalui demokrasi tidak akan bertentangan dengan konstitusi sebagai hukum tertinggi (Holcombe, 2001; Olatunji, 2013; Radjab, 2013; Suhartini, 2019).

Partai politik merupakan suatu sarana bagi warga Negara untuk berpartisipasi dalam mengolah Negara, sehingga terbentuknya suatu lembaga dan melahirkan sejarah yang panjang. Partai politik ini mempunyai peran penting dalan suatu bernegara karena sangat eratnya aktivitas dalam pemerintahan. Untuk menghindari pembubaran diperlukannya mekanisme hukum yang memberikan kelangsungan hidupnya suatu partai. (Budiarjo, 2013)

Dalam partai politik, perkembangan kontestasi pemilu membentuk suatu sistem yang demokrasi dan pemilu demokrasi. Setelah Indonesia memiliki mahkamah konstitusi, maka dalam hal pembubaran suatu partai, kewenangan berada dalam tangan mahkamah konstitusi yang berwewenang dalam proses peradilan danmemiliki jaminan akan keterbukaan proses pengadilan(Antari, 2014; HSB, 2013; Setyaningrum, 2010). Pembubaran partai politik diyakini sebagai mekanisme untuk melakukan pengawasan terhadap partai poltik.

Berdasarkan latar belakang di atas, penelitian ini dilakukan dengan tujuan mendeskripsikan bagaimana kewenangan Mahkamah Konstitusi dalam membubaran partai politik di Indonesia dan bagaimanamekanisme pembubaran partai politik.

\section{METODE PENELITIAN}

Penelitian ini didesain dengan menggunakan pendekatan penelitian hukum normatif. Penelitian ini doktrinal atau sering disebut sebagai penelitian perpustakaan atau studi dokumen. Untuk membahas rumusan masalah, penelitian ini menggunakan pendekatan perundang-undangan. Pendekatan dilakukan dengan menelaah Undang-Undang yang berkaitan dengan masalah dalam penelitian ini. Sumber data penelitian ini adalah hasil dari catatan, pendapat para ahli, dan Undang-Undang tentang kewenangan Mahkamah Konstitusi. Bahan hukum yang digunakan adalah bahan hukum primer, yaitu bahan hukum yang diperoleh melalui peraturan perundang-undangan yang berlaku di Indonesia, dan bahan hukum sekunder, yaitu bahan hukum yang diperoleh dari hasil buku-buku, pendapat dari masyarakat, serta doumen yang berkaitan tentang partai politik seperti Undang-undang yang ada di Indonesia.

Dalam rangka memperoleh data yang relevan dengan pembahasan tulisan ini, teknik pengumpulan bahan hukum yang digunakan adalah studi pustaka. Bahan hukum yang dikumpulkan dalam penelitian ini baik dari bahan hukum primer maupun data sekunder disusun secara sistematis, diolah dan dianalisis secara kualitatif dengan menggunakan interprestasi hukum dan argumentasi hukum secara deduktif-induktif.Setelah itu hasilnya disajikan secara deskriptif analisis.

\section{HASIL PENELITIAN DAN PEMBAHASAN}

\section{Kewenangan Mahkamah Konstitusi dalam Pembubaran Partai Politik}

Kebebasan kelompok untuk membuat sebuah partai dijamin oleh badan hukum. Disamping harus memenuhi syarat, hak, dan kewajiban, partai politik juga tidak luput dari pelanggaran aturan-aturan yang bisa mengakibatkan pembumbaran.Pelanggaran itu tidak semua bisa dijadikan untuk membubarkan partai politik, sanksi bagi partai politik terbukti melangggar aturan dikenai sanksi administrstif dan sanksi pidana (Widayati, 2011). Bentuk sanksi dilihat dari kutipan pasal 47 ayat (5) undang undang nomor 2 tahun 2008 diberikan hukuman berupa sanksi adminstratif, pembekuan sementara partai politik yang disahka oleh lembaga yang mejaga martabat partai politik dan anggota.

Sepatutnya makna sanksi pidana tidak lebih dari persoalan alamiah yang memiliki makna kesatuan hukum. Oleh sebab itu, pembuat peraturan yang hanya mengatur pertanggung jawaban pidana pengurus badan korporasi tercantum dalam pasal 59 KUHP, yaitu dalam hal pelanggaran ditentukan pidana terhadapyang bersangkutan ternyata tidak ikut campur dalam tindak pidana. Ketika partai politik disebut sebagai badan hukum, maka partai politik tersebut masuk dengan subjek hukum pidana, yaitu apakah partai politik dapat mempunyai kesalahan baik yang dilakukan secara sengaja maupun kelalaian atau kealpaan.Sejatinya partai politik tidak dapat diproses pidana, tetapi pengurus partai politik dapat diproses secara pidana dalam pemidanaan yang dijatuhkan kepada pelaku supaya dapat berpengaruh untuk mayarakat, terutama untuk yang akan melakukan pelanggaran. Tujuan pemidanaan adalah mencegah para pelaksana atau anggota partai politik mengulangi melanggar aturan hukum.

Setelah membahas tentang larangan dan pembubaran partai politik menurut Undang-undang Nomor 2 Tahun 2008 tentang Partai Politik pada sub Bab sebelumnya, maka berdasarkan ketentuan yang termuat dalam pasal tersebut, dapat dipahami dalam sebuah partai pemerintah memiliki kekuasaan 
untuk mengawasi pelanggaran baik dalam dapartemen dalam negeri atau dapartemen hukum dan HAM diatur dalam undang undang. Putusan Mahkamah Konstitusi dalam permohonan pembubaran partai tersebut wajib diputuskan dalam jangka waktu paling lambat 60 hari kerja setelah permohonan dibuat dalam registrasi perkara konstitusi.

Syarat dalam mengajukan pembubaran harus mengikuti instruksi dari Mahkamah Konstitusi salah satunya yang pertama harus melakukan permohonan kedua permohonan harus sesuai dengan idiologi, asas, tujuan dan kegiatan politik yang bersangkutan.Jika salah satu dari ketiganya ditemukan bukti adanya hal-hal yang bertentangan dengan Undang-undang Dasar Negara Republik Indonesia 1945, maka Mahkamah Konstitusi dapat membubarkan Partai Politik yang bersangkutan dengan putusan bersifat final dan mengikat. Dengan demikian dalam pembubaran itu dilakukan oleh menteri dengan mengumumkan dalam bentuk berita Negara berdasarkan putusan pengadilan yang berkekuatan tetap. Artinya adalah Pembubaran partai tersebut tidak dari putusan pengadilan melainkan sejak diumumkanya dalam berita Negara.

Selama ini partai politik bubar karena membubarkan diri atas kemauannnya sendiri bahkan juga dengan gabungan dengan partai lain. Dengan masalah lainya yang membubarkan partai politik adalah murni mahkamah konstitusi. Pemerintah hanyalah bertindak sejak administratur yaitu memuat dalam berita Negara secara resmi.Pasal 73 ayat (1) UU No. 24 Tuhan 2003 tentang Mahkamah Konstitusi menentukan,pelaksanaan putusan pembubaran partaipolitik dilihat didalam pasal71, dilakukan dengan pembatalan pembubaran dalam pemerintah. Sedangkan pasal 47 menetukan putusan mahakamah konstitusi memperoleh kekuatan hukum tetap sejak selesai diucapkan dalam sidang pleno terbuka untuk umum. Jika dipahami secara sederhana saja, ketentuan diatas menunjukkan bahwa putusan Mahkamah Konstitusi dalam perkara ini bersifat deklaratior dengan menyatakan bahwa partai politik yang bersangkutan bubar atau dibubarkan sejak putusan itu diucapkan dalam sidang pleno terbuka.

Wewenang Mahkamah Konstitusi mengadila dari tingkat pertama sampai yang terakhir yang bersifat final untuk (Amsari, 2019):

a) menguji undang-undang terhadap Undang-Undang Dasar Negara RepublikIndonesia Tahun 1945

b) memutus sengketa kewenangan lembaga negara yang kewenangannya diberikan oleh UndangUndang Dasar Negara Republik Indonesia Tahun 1945;

c) memutus pembubaran partai politik; dan

d) memutus perselisihan tentang hasil pemilihan umum.

Meskipun Mahkamah Konstitusi baru dibentuk zaman era reformasi,lembaga ini mempunyai kedudukan yang sama dengan lembaga lainnya yang telah ada sebelumya. Oleh karena itu, dalam pelaksanaan tugas Mahkamah Konstitusi lebih mudah dan cepat. Membubarkan Partai Politik merupakan kewenangan yang dimiliki oleh lembaga Negara, yaitu Mahkamah Konstitusi. Mahkamah Konstitusi merupakan salah satu lembaga kehakiman yang berfokus pada pengawalan serta penafsir konstitusi. Oleh karenanya, Mahkamah Konstitusi diberikan kewenangan untuk menyelesaikan pelanggaran terhadap hak-hak konstitusi yang terjadi. Pembubaran Partai Politik menjadi kewenangan Mahkamah Konstitusi karena telah diatur di dalam UUD NRI berdasarkan kepada beberapa alasan termasuk diantaranya pelanggaran konstitusional.

\section{Mekanisme dalam Pembubaran Partai Politik di Indonesia}

Adapun beberapa tatacara dalam perkara pembubaran partai politik di Mahkamah Konstitusi sebagai berikut(Azed \& Amir, 2005):

a) Pengajuan Permohonan

b) Pendaftaran Permohonan dan Jadwal Sidang

c) Pemeriksaan Pendahuluan

d) Pemeriksaan Persidangan

e) Rapat Permusyawaratan Hakim

f) Putusan Mahkamah konstitusi

Berhubungan pembahasan mengenai hukum yang dicita-citakan yang akan datang ada prosedur dalam pembubaran partai politik diindonesia ada dua tahap, pertama yaitu tahap pengajuan permohonan kepada Mahkamah Konstitusi, dan kedua yaitu tahap persidangan di Mahkamah Konsitusi.

Putusan pembubaran partai politik yang dijatuhkan oleh Mahkamah Konstitusi sebagaimana penulis uraikan diatas kemudian menimbulkan akibat hukum antara lain: 
a) Pelarangan hak hidup partai politik dan penggunaan simbol-simbol partai tersebut di seluruh Indonesia;

b) Lararangan mengunakan simbol simbol partai yang dibubarkan;

c) Memberhentikan semua pejabat yang berasal dari partai yang dibubarkan;

d) Melarang mantan pengurus partai yang dibubarkan dalam kegiatan politik;

e) Pengambilan kekayaan yang dimiliki partai yang dibubarkan kepada Negara.

Pembubaran partai politik di Mahkamah Konstitusi diawali dengan mengajukan permohonan oleh pemohon, yang mana pemohon dalam perkara pembubaran partai politik adalah pemerintah, pemerintah adalah pemerintah .Permohonan yang telah memenuhi kelengkapan dicatat dalam buku registrasi perkara konstitusi (BRPK) kemudian pemeriksaan perkara yang dilakukan dalam beberapa tahap.Pertama, pemeriksaan adminstratif. Kedua, pemeriksaan pendahuluan. Ketiga, tahap pemeriksaan persidangan. Keempat, tahap permusyawaratan dan pengambilan keputusan. Kelima, tahap penyampaian pengumuman keputusan serta kedudukan hukuman pemohon didalam perkara pembubaran partai politik di Mahkamah Konstitusi dianggap sah apabila telah memenuhi syarat yang telah ditentukan.

Jika dilihat pada zaman Orde Lama dan sebelum Reformasi, peraturan mengenai akibat hukum yang timbul oleh karena pembubaran suatu partai politik termuat didalam Pasal9 Peraturan Presiden Nomor 13 Tahun 1960. Sedangkan pada masa setelah Reformasi, ketentuan akibat hukum pembubaran partai politik di Indonesia diatur dalam Peraturan Mahkamah Konstitusi (PMK) Nomor 12 Tahun 2008 Pasal 10 Ayat (2). Adapun beberapa akibat hukum yang mucul dari pembubaran partai politik tersebut, sebagai berikut:

a) Akibat terhadap hak dan kewajiban yang menyangkut dilaur

b) Akibat terhadap jabatan yang terpilih seperti Presiden dan Wakil Presiden, Anggota DPD, Anggota DPR dan DPRD

c) Akibat terhadap status pengurus dan anggotanya

d) Akibat terhadap hak dan kewajiban yang didalam.

e) Pengaturan tentang akibat hukum dalam pembubaran tersebut.

Timbulnya masalah antara pribadi pengurus dengan pribadi keanggotan bukan masalah antara oranisasi,tetapi masalah pribadi antara perorangan. Jika masalah itu terjadi antara pengurus yang secara resmi mewakili instiutusi dengan pribadi anggotanya,maka itu ada hubungan hukum dengan institusi partai dan anggota partai. Jadi, hal itu juga disebut permasalahan yang harus diselesaikan sendiri oleh partai politik.

Pembubaran partai politik menjadi salah satu isu hukum yang diatur dalam peraturan perundangundangan di Indonesia, sehingga dalam suatu pembubaran partai politik akan selalu memiliki akibat hukum, tak terkecuali kepada anggotanya yang duduk sebagai Dewan Perwakilan Rakyat. Berdasarkan temuan awal, baik dalam Undang-undang No. 24 Tentang Mahkamah Konstitusi maupun Undangundang No. 2 Tahun 2008 tentang Partai Politik, tidak ada pasal yang mengatur secara tegas mengenai akibat hukum yang terjadi kepada anggota Dewan Perwakilan Rakyat apabila partai politiknya dibubarkan.

\section{SIMPULAN DAN SARAN}

\section{Simpulan}

Berdasarkan hasil analisis data penelitian ini, ada beberapa simpulan yang dapat dibuat, yaitu: pertama, Mahkamah konstitusi merupakan salah satu lembaga yang melakukan kekuasaan kehakiman yang merdeka untuk penyelenggara pengadilan dan untuk menegakkan hukum dan keadilan.MK berwewenang mengadilan dalam tingkat pertama sampai yang terakhir yang putusannya bersifat nyata. Membubarkan partai politik yang melanggar Undang Undang Dasar Negara Republik Indonesia merupakan kewenagan yang dimiliki oleh lembaga Negara, yaitu Mahkamah Konstitusi untuk membubarakan partai. Kedua, ada beberapa prosedur perkara pembubaran partai politik diMK, yaitu: mengajukan permohonan,mendaftarkan permohonan,melihat jadwal sidang perkara,memeriksa pendahuluan, pemeriksaaan persidangan,rapat para hakim dan putusan MK. Selain itu, ada beberapa akibat hukum dari pembubaran pertai politik tersebut, yaitu akibat kepada hak dan kewajiban dari eksternal,terhadap jabatan yang dipilih,akibat terhadap pengurus dan para angggota,akibat terhadap hak dan kewajiban internal dan pengaturan mengenai akibat dalam hukum pembubaran. 


\section{Saran}

Selain hasil penelitian, ada beberapa saran yang perlu disampaikan kepada beberapa pihak, yaitu: kepada pengurus partai untuk melaksanakan tugas dan kewajibannya sesuai dengan hukum dan undangundang yang berlaku, sehingga pembubaran partai tidak terjadi, dan bagi penegak hukum khususnya Mahkamah Konstitusi untuk memberlakukan hukum yang seadil-adilnya, sehingga keamanan dan ketentraman Negara tetap terjaga.

\section{DAFTAR PUSTAKA}

Amsari, F. (2019). Bisakah MK Memutus Sengketa Lembaga Negara yang Terkait dengan Dirinya? Retrieved from https://www.hukumonline.com/klinik/detail/ula san/lt5cd543f6991ff/bisakah-mkmemutus-sengketa-lembaga-negara-yang-terkait-dengan-dirinya/

Antari, P. E. D. (2014). Kewenangan Pembubaran Partai Politik oleh Mahkamah Konstitusi Ditinjau dari Perspektif Hak Asasi Manusia (Ham). Jurnal Magister Hukum Udayana, 7(3), 383-394. https://doi.org/10.24843/jmhu.2014.v03.i03.p03

Azed, A. B., \& Amir, M. (2005). Pemilu dan Partai Politik di Indonesia. Jakarta: Pusat Studi Hukum Tata Negara Fakultas Hukum Universitas Indonesia.

Budiarjo, M. (2013). Dasar-Dasar Ilmu Politik (Revisi). Jakarta: PT Gramedia Pustaka Utama.

Holcombe, R. G. (2001). Constitutions and Democracy. The Annals of the American Academy of Political and Social Science, 7(1), 1-11. https:/doi.org/10.1177/000271623316900102

HSB, A. M. (2013). Mahkamah Konstitusi sebagai Neutralizer terhadap Lembaga Politik. Jurnal Rechtsvinding, 2(3), 315-330. Retrieved from https $/ /$ rechtsvinding.bphn.go.id/artike1/ART 2 JURNAL VOLUME 2 NO 3_PROTEKSI-1.pdf

Olatunji, F. O. (2013). Democracy and the Challenge of the Rules of Law in Developing Democratic Society. Beytulhikme An International Journal of Philosophy, 3(2), 67-79-79. https://doi.org/10.18491/bijop.44013

Radjab, S. (2013). Negara Hukum Demokratis: Konstitusionalisme, Rule of Law dan HAM. 8(2), 93101. Retrieved from http://journal.uin-a lauddin.ac.id/index.php/sls/artic le/download/1282/1246

Setyaningrum, M. (2010). Kewenangan Mahkamah Konstitusi dalam Upaya Penyelesaian Pembubaran Partai Politik dalam Sistem Ketatanegaraan Republik Indonesia (Universitas Islam Indonesia). Retrieved from https://dspace.uii.ac.id/bitstream/handle/123456789/8645/RTN 254.pdf? sequence $=1 \&$ is Allowed $=\mathrm{y}$

Suhartini. (2019). Demokrasi dan Negara Hukum. Jurnal Hukum Fakultas Hukum Universitas Balikpapan, 11(1). https://oi.org/10.36277/.v11i1.42

Widayati. (2011). Pembubaran Partai Politik dalam Sistem Ketatanegaraan Indonesia. Jurnal Hukum, $X X V I(2)$.

Undang-Undang Nomor2 Tahun2011tentangPartai Politik 